\title{
A Case of Cerebral Salt Wasting Syndrome after Surgical Excision of a Giant Acoustic Neuroma
}

\author{
Yong Cheol Koo, Chi Sang Hwang, Seung Hyun Koh and Won-Sang Lee \\ Department of Otorhinolaryngology, Yonsei University College of Medicine, Seoul, Korea
}

청신경종 제거수술 후 발생한 대뇌성 염소모 증후군

구용철 · 황치상 · 고승현 · 이원상

연세대학교 의과대학 이비인후과학교실

\author{
Received December 4, 2011 \\ Revised May 9, 2012 \\ Accepted May 10, 2012 \\ Address for correspondence \\ Won-Sang Lee, MD, PhD \\ Department of Otorhinolaryngology, \\ Yonsei University \\ College of Medicine, \\ 50 Yonsei-ro, Seodaemun-gu, \\ Seoul 120-752, Korea \\ Tel $+82-2-2228-3606$ \\ Fax $+82-2-393-0580$ \\ E-mail wsleemd@yuhs.ac
}

Cerebral Salt Wasting Syndrome (CSWS) is defined as the development of extracellular volume depletion due to a dysfunction of the renal sodium transport system. Differentiation of CSWS from the Symdrome of Inappropriate Secretion of Antidiuretic Hormone in patients with intracranial disease is difficult because both syndromes include hyponatremia and concentrated urine with natriuresis. However, distinguishing between these two syndromes is very important because the treatment options differ. We report a 41 year-old Asian woman who presented initially with hyponatremia, and was finally diagnosed with CSWS after an operation for an acoustic neuroma. Based on this case, we discuss a possible mechanism and disclose insights about differential diagnosis thereof.

Korean J Otorhinolaryngol-Head Neck Surg 2012;55:390-4

Key Words Hyponatremia Cerebrum - Neuroma Acoustic.

\section{서 론}

저나트륨혈증은 거미막 출혈, 종양, 외상성 뇌의 손상과 같 은 다양한 중추 신경계의 질환에서 드물지 않게 관찰되는 소 견이다. ${ }^{1,2)}$

이러한 저나트륨혈증 환자에서 가장 우선적으로 고려되는 것이 대뇌성 염소모 증후군(Cerebral Salt Wasting Syndrome, CSWS)과 항이뇨 호르몬 분비 이상 증후군(Syndrome of Inappropriate secretion of Anti-Diuretic Hormone, SIADH)이며, 임상적으로 이 두 질환을 감별하기는 쉽지 않다.,4)

저나트륨혈증은 중추신경계 질환 환자에서 중추신경계의 삼투질 농도(osmolarity)의 조절에 관여하여 환자의 상태를 악화시키고 회복을 지연시키는 데 중요한 역할을 하며, ${ }^{1,34)}$ 두개 내 종양수술 후에 합병증으로 올 수 있는 다른 뇌신경계 질환 과의 감별이 늦어질 경우 자칫 치명적인 결과를 초래할 수 있 게 되어 주의를 요하는 질환이다. 아직까지 이비인후과적으로
청신경종 수술 후에 발생한 저나트륨혈증에 대한 보고는 많 지 않으며, 본 저자들은 경와우 접근법으로 청신경종을 제거 한 후에 발생한 대뇌성 염소모 증후군을 경험하여 문헌 고찰 과 함께 보고하는 바이다.

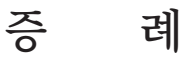

41세 여자 환자가 2년 전 우측 청력에 감소가 있어 다른 병 원 신경외과에 내원하여 우측 청신경종으로 진단받고 2008년 2월 구불정맥굴 뒤 접근법(retrosigmoid approach) 하 개두술 및 종양 절제수술을 시행 받은 이후, 2008년 6월 잔여 종물에 대하여 감마나이프 시술(gamma knife surgery, GKS)을 받았 으나, 이후 추적 관찰 중 잔여 종물의 크기가 증가한 소견을 보 여 본원 이비인후과에 의뢰되었다. 환자는 특이 내과적 과거력 및 그 외 가족력상 특이한 사항은 없었다. 환자는 종물의 종괴 효과로 인하여 우측 시력저하, 우측 안면의 감각 저하, 우측의 
복시, House-Brackmann Grade(HBG) III의 우측 안면마비, 우측 청각소실, 좌측으로의 설편위, 편측에 국한되어 움직일 수 있고, 근육 수축도 있으나 저항을 이기지 못하는 정도의 우 측 상하지의 grade IV의 운동능력 저하 및 보행장애 증상이 있었다. 이학적 검사상 양측 고막은 정상소견이었으며, 수술 전 후두경 소견상 양측 성대의 움직임은 정상이었다. 수술 전 시행한 심전도, 단순 흥부 촬영, 혈액검사 및 소변 검사는 모 두 정상 범위였다. 2007년 11월 시행한 환자의 이전 측두 자기 공명영상(temporal MRI)에서는 우측 소뇌 교각부(cerebellopontine angle)에 $2.8 \mathrm{~cm}$ 의 청신경종 소견을 보이고 있었으 며, 감마나이프 시술 2년 후 2009년 시행한 측두 자기공명영 상에서는 우측 소뇌 교각부에 $2.5 \mathrm{~cm}$ 크기의 종물 소견을 보 이고 있었다. 그러나 본원 이비인후과에서 2010년 3월에 시행 한 측두 자기공명영상에서는 우측 소뇌 교각부에 $4 \mathrm{~cm}$ 크기 의 종물 소견(Fig. 1)을 보이고 있었고 이 종물은 낭성 부분(cystic portion)을 포함하고 있었으며, 뇌간 부위를 압박하고 있 는 소견이었다. 우측의 잔존한 청신경종의 치료를 위하여, 저 자들이 이전 논문에 소개한 바 있는 술식인 rope-skipping technique ${ }^{5)}$ 및 경와우접근법(transcochlear approach)을 이 용하여 충분한 수술 시야 확보를 계획한 후 우측 청신경종 절 제술을 시행하였다. 수술 소견상 소뇌 및 상전정 신경은 종양 의 종괴 효과로 인하여 각각 후방과 상내측으로 밀려있었으 며, 이전 수술 및 GKS의 영향으로 종양과 유착이 심하였다. 그러나 종양의 내측에 위치하고 있던 안면 신경과 와우 신경 및 전하소뇌동맥은 종양과 유착되어 있지 않아 손상 없이 보 존할 수 있었다. 종양을 성공적으로 제거(total resection)하였 으나, 종양의 크기가 커 종양 및 소뇌를 견인하는 과정에서 종 양 주변부의 미세 혈관에서 출혈 소견이 있었으며, 이로 인하 여 미세 혈관의 손상 가능성은 배제할 수 없는 소견이었으나 수술 중 환자의 활력 징후는 정상 수준을 유지하였다.
수술 직후에도 환자의 활력 징후 및 의식 상태는 정상 수준 을 유지하였다.

수술 후 2일째 오전에 시행한 혈액검사상 혈청 나트륨 수치 가 $121 \mathrm{mmol} / \mathrm{L}$ 로 보고되어 $3 \%$ 생리식염수를 $50 \mathrm{~mL} / \mathrm{hr}$ 로 투여하였으나, 7시간 경과한 오후에도 혈청 나트륨 수치는 113 $\mathrm{mmol} / \mathrm{L}$ (Fig. 2)으로, 혈청 삼투질농도는 $234 \mathrm{mmol} / \mathrm{L}$ 으로 감 소하는 소견(Fig. 3)을 보였으며, 소변 나트륨 수치가 $187 \mathrm{mmol} /$ $\mathrm{L}$ 로 증가하는 소견을 보였다. 의식상태는 기면(drowsy) 상태 로 변화하였고, 구음장애(dysarthria) 및 우측 상하지의 운동 기능 저하 소견이 악화되었으며, 약 1 분간의 대발작(generalized tonic-clonic seizure)이 나타났다. CSWS로 인한 저나트 륨혈증 의심하에 즉각적으로 $3 \%$ 생리식염수를 $50 \mathrm{~mL} / \mathrm{hr}$ 에 추가적으로 $20 \%$ mannitol을 $1000 \mathrm{~mL} / \mathrm{day}$, 생리식염수를 약 $1000 \mathrm{~mL} /$ day 및 hydrocortisone을 $1200 \mathrm{mg} / \mathrm{day}$ 로 정맥 투 여하여 치료를 시작하였다. 대발작 6시간 경과 후 시행한 뇌혈 관 자기공명영상(Brain MR Angio) 상 출혈 및 경색 소견은 명확하게 관찰되지 않아 중환자실에서 경과 관찰하였다. 이후 24시간 소변량은 $5300 \mathrm{~mL}$ 로 측정되었으며, 1 일 경과 후 혈청 나트륨 수치는 $124 \mathrm{mmol} / \mathrm{L}$ (Fig. 2), 혈청 삼투질 농도는 272 $\mathrm{mOsmol} / \mathrm{L}$ (Fig. 3)으로 측정되었다. 갑상선, 부신, 신장, 간기 능은 혈액 검사상 모두 정상이었다. 환자의 의식 상태는 큰 호 전은 없었으나 환자의 저나트륨혈증은 발생 7일째 정상범위 로 회복되어 $3 \%$ 생리식염수, $20 \%$ mannitol 및 hydrocortisone 투여를 점감하여 중지하였으며, 생리식염수는 약 1000 $\mathrm{mL} / \mathrm{day}$ 로 유지하였다. 환자의 조직 병리학적 소견은 신경집 종(schwannoma)으로 진단되었다. 환자의 의식 상태는 수술 후 9일째부터 서서히 호전되는 양상을 보였으며, 수술 후 43 일째 의식상태는 완전히 정상으로 회복되어 퇴원하였다.

환자는 퇴원 후 재활치료를 시행하며 보행장애 및 편측에 국한된 우측 상하지의 운동 기능 저하는 호전되는 양상을 보
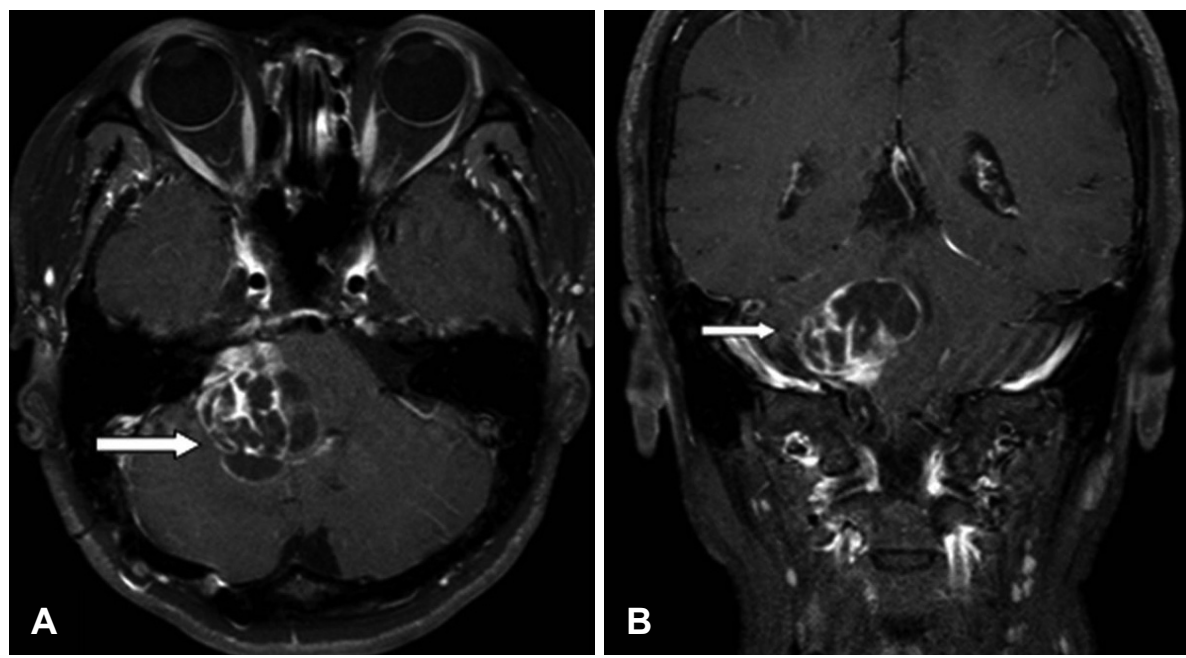

Fig. 1. Brain magnetic resonance image (A: gadolinium enhanced T1 axial view imaging, $\mathrm{B}$ : gadolinium enhanced T1 coronal view imaging) before the surgery revealed an approximately $4 \times 4 \mathrm{~cm}$ sized cystic mass at the right cerebellopontine angle (arrow). 


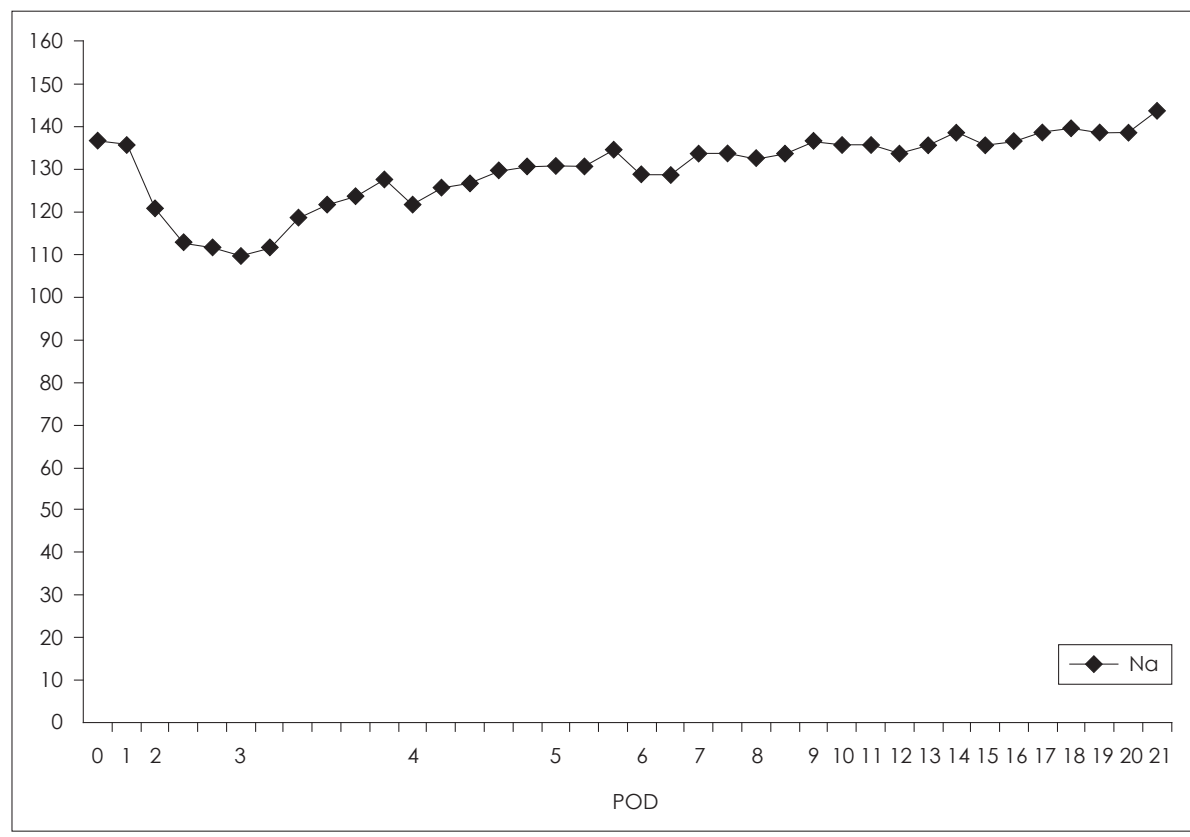

Fig. 2. Plasma sodium concentrations from the operation day to the $21^{\text {st }}$ day after surgery (normal range: 135.0 145.0 mmol/L). POD: Post-Operative Day.

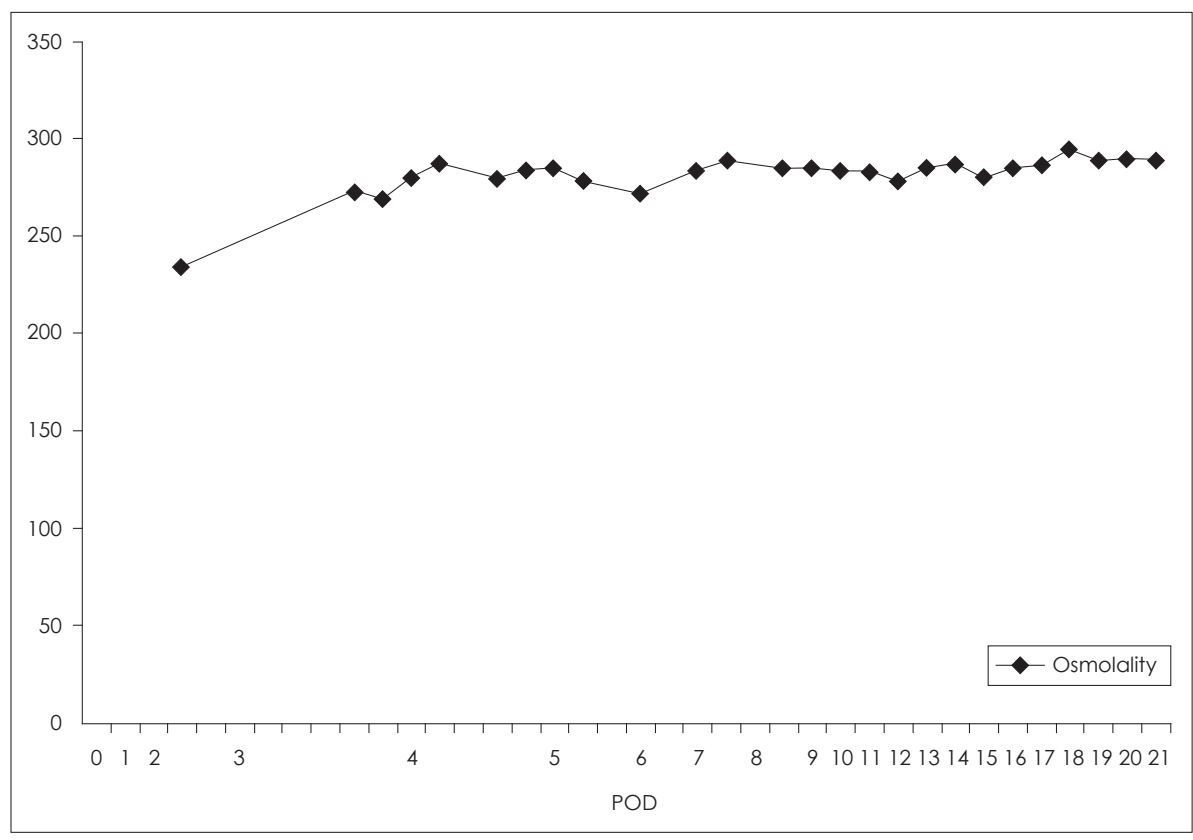

Fig. 3. Plasma osmolality from the operation day to the $21^{\text {st }}$ day after surgery (normal range: $289.0-308.0 \mathrm{mOsm} / \mathrm{kg}$ ). POD: Post-Operative Day.

였고 수술 후 5 개월째 외래 내원하여 시행한 이학적 검사상 우측의 안면마비는 HBG II로 호전된 양상을 보였으며, 현재 수술 후 19 개월째이며, 종양은 재발하지 않은 상태로 주기적 으로 외래 추적 관찰 중이다.

\section{고 찰}

청신경종의 수술은 1894년 Sir Charles Balance에 의해서 시도된 이후 사망률이 $20 \%$ 이상이었으나 많은 발전을 거듭하 면서 그 사망률과 합병증 빈도를 낮춰왔다. 1964년 William
House는 수술 현미경과 고속 드릴을 도입하여 경미로 접근법 으로 청신경종을 제거하였으며, 이후에도 뇌신경 모니터링(cranial nerve monitoring), neuroanesthesiological techniques 등의 발달로 인하여 현재 사망률은 $1 \%$ 이하로 감소하였 다. ${ }^{6-9)}$ 비록 경미로/경와우 접근법 등을 포함한 청신경종의 수 술에서 사망은 더 이상 주요한 두려움은 아니지만, 수술 중이 나 수술 후에 발생할 수 있는 뇌신경 장애, 뇌척수액 누출, 뇌 막염, 뇌출혈 같은 주요 합병증은 환자를 매우 위험한 상황에 빠질 수 있게 하기 때문에 청신경종을 수술하는 경우 수술 중 이나 수술 후 항상 주의를 기울여야 한다. 


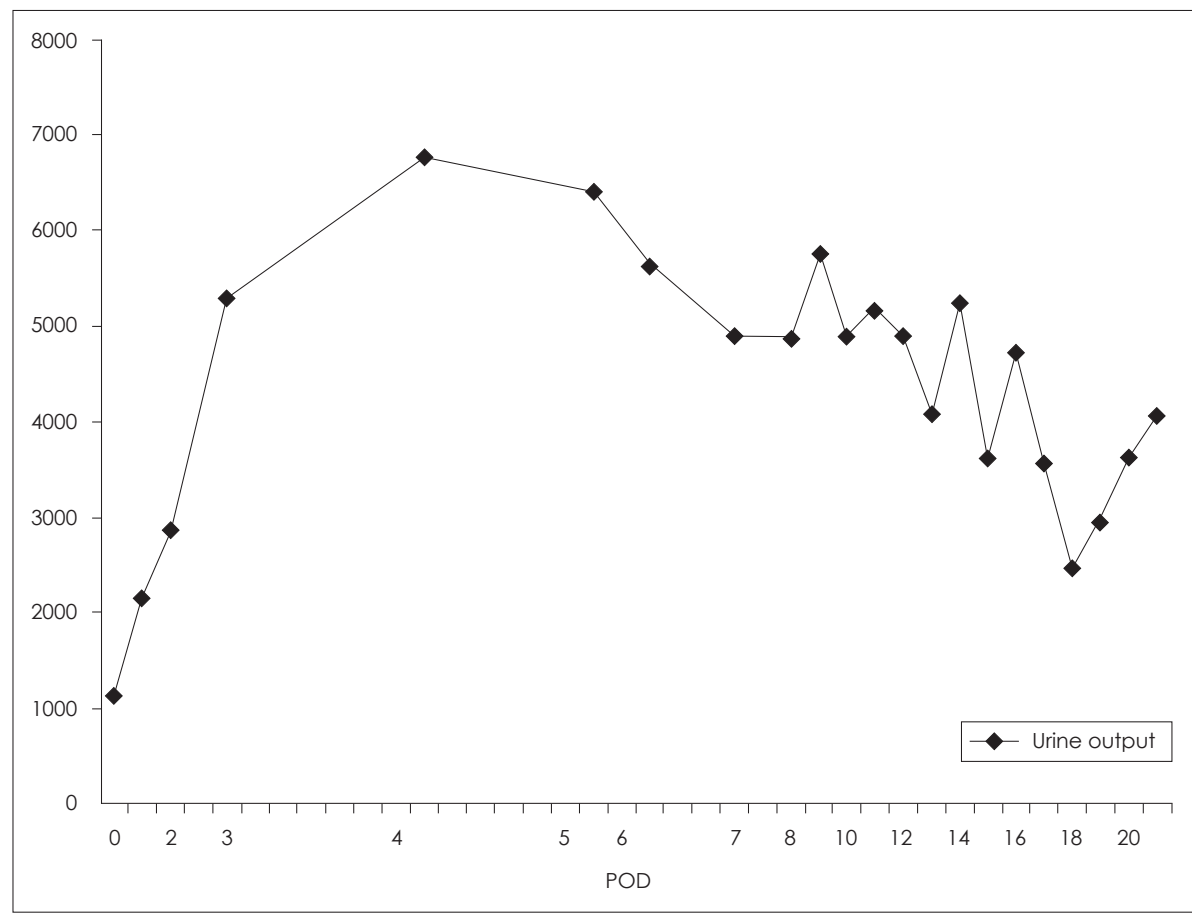

Fig. 4. Urine output from the operation day to the $21^{\text {st }}$ day after surgery (mL/day). POD: Post-Operative Day.
경미로 접근법의 합병증으로는 위에서 설명한 합병증 이외 에도 청각 소실, 전정기능 장애 및 현훈, 안면신경마비, 9번 신 경마비, 10 번 신경마비 등의 뇌신경 마비, 두통 등이 있을 수 있다. ${ }^{9}$ 하지만, 본 증례와 같은 저나트륨혈증은 아주 드물게 보 고되고 있다. ${ }^{1)}$

저나트륨혈증은 중추신경계 질환 환자에서 경련을 유발하 거나 신경학적 증상을 악화시킬 수 있어 이에 대한 적절한 치 료는 매우 중요하다.

이는 일반적으로 두개내 수술시 나타날 수 있는 시상하부 및 뇌하수체의 일시적인 경색에 의한 것으로 사료된다. 두개 내 수술시 이들 구조로 혈류를 공급하는 작은 혈관들에 직, 간접적인 손상이 나타날 수 있으며, 이로 인하여 혈류량의 감 소에 따라 나타날 수 있는 미세혈전증 등에 의하여 일시적인 경색 등의 합병증이 나타날 수 있는 것으로 보고되어 있다. ${ }^{10)}$

본 저자들은 본 증례의 경우 수술시에 시야 확보가 힘들었 으며, 이로 인하여 시야 확보를 위하여 적용한 뇌의 견인 과정 및 종양이 일으키고 있던 종괴 효과가 사라지며 나타날 수 있 는 작은 혈관들의 직, 간접적인 손상 및 미세혈전증에 의하여 나타난 일시적인 뇌허혈에 의한 것으로 생각된다.

소아의 뇌종양 수술 후 CSWS 발생에 대한 Jiménez 등 ${ }^{11}$ 의 논문에 의하면 이러한 경우 수술 후 48시간경부터 증상이 나타나기 시작하며, 적절한 치료를 할 경우 심각한 신경학적 합병증을 막을 수 있는 것으로 알려져 있으며, 회복기간은 $6 \pm$ 5일로 알려져있다.

두개내 수술을 받은 후 저나트륨혈증은 CSWS 또는 항이
뇨 호르몬 분비이상 증후군(SIADH)에서 나타나며, 이 두 질 환을 감별하는 것은 쉽지 않다.

두 질환의 감별에 있어서 일반적인 혈액 검사 소견은 도움이 되지 않으며, 정확한 감별을 위해서는 혈장량이나 총 혈액량 의 측정이 필요하므로 임상에서 정확하게 접근하기는 쉽지 않 은 것이 현실이다. ${ }^{1,3)}$ 임상적으로 CSWS 진단에 적합한 몇 가 지 특징들을 제시해 보면, 소변량과 소변 나트륨 분비가 SIA$\mathrm{DH}$ 에서 보다 많고, $\mathrm{ADH}$ 농도가 정상이며 다뇨와 과도한 나 트륨 소실 및 체중 감소를 보인다는 것이다. 또한 ANP나 brain natriuretic peptide 같은 나트륨 이뇨 펩타이드의 증가 소견 이 도움을 줄 수 있다(Fig. 4). ${ }^{1,3,4,12)}$

본 증례의 경우 의식혼탁, 경련, 사지 운동 저하 등의 증상 과 함께 저나트륨혈증, 다뇨(Fig. 4)와 소변 나트륨의 분비 증 가 등의 특징을 보여 SIADH보다는 CSWS에 부합하는 소견 이라고 할 수 있겠다. 하지만, 환자의 체액 상태를 확인할 수 있 는 중심정맥압의 측정과 이에 대한 모니터링이 있었다면 좀 더 확실한 진단과 적절한 수액치료를 할 수 있었을 것으로 생 각된다.

두개내 질환이 CSWS의 병태생리에 대해서는 아직 확실하 게 알려져 있지 않지만, atrial nitric uretic peptide, brain natriuretic peptide, $\mathrm{C}$-type natriuretic peptide, dendroaspis natriuretic peptide와 같은 나트륨 이뇨 인자(natriuretic factor)들이 주요 역할을 할 것이라고 생각하고 있다. ${ }^{3,4}$ 혈장량이 증가하게 되면 혈관벽이 팽창하게 되며 이로 인하여 교감신경 계가 자극되어 Angiotensin II나 Endoteline 분비가 증가하 
고 이로 인하여 Natriuretic peptide의 분비가 증가하여 distal tubule에 작용하여 CSWS가 일어난다고 여겨지고 있다. ${ }^{3)}$ 이 두 질환의 감별이 중요한 이유는 근본적으로 치료 방법 에 차이가 있기 때문이다. 즉 CSWS는 수액과 나트륨의 공급 이 필요하고, SIADH에서는 수액 공급을 제한하는 것이 일 차적인 치료 방법이기 때문이다. ${ }^{13)}$ 만일 환자가 CSWS에 대해 서 수액 제한 치료를 받는다면, 치명적인 저혈량증과 뇌허혈이 나타날 수 있을 것이며, 반면에 만일 SIADH 환자에게 나트륨 과 수액을 공급한다면 이는 뇌의 수축을 유발할 수 있으며, 이러한 뇌의 비정상적인 수축으로 인하여 뇌교 주위의 신경 조직의 탈수초화가 일어나는 뇌교수초용해증(central pontine myelinolysis)이나 삼투성 탈수초질환(osmotic demyelination)과 같은 합병증이 나타날 수 있을 것이다. ${ }^{14)}$

경미로 접근법 ${ }^{15)}$ 또는 경와우 접근법 ${ }^{16)}$ 을 이용하여 청신경 종양을 제거한 이후에 환자가 의식혼탁이 오거나, 경련, 사지 운동 저하 등의 증상이 발생한다면 뇌혈관계의 질환을 먼저 생각하여 이에 집중하게 된다. 하지만 드물게 저나트륨혈증과 같은 전해질 이상도 이와 유사한 증상을 일으킬 수 있기 때문 에 항상 간과하여서는 안 될 것이며, 청신경종의 수술 이후 저 나트륨혈증이 발생하였을 경우 반드시 CSWS와 SIADH를 감별하여 본 증례와 같은 CSWS일 경우 수액과 나트륨을 공 급하는 적절한 치료를 하는 것이 필요하겠다.

\section{REFERENCES}

1) Roca-Ribas F, Ninno JE, Gasperin A, Lucas M, Llubiá C. Cerebral salt wasting syndrome as a postoperative complication after surgical resection of acoustic neuroma. Otol Neurotol 2002;23(6):992-5.

2) Kang SY, Kang JH. Cerebral salt wasting syndrome following tha- lamic infarction. Korean J Stroke 2003:5(1):115-7.

3) Cerdà-Esteve M, Cuadrado-Godia E, Chillaron JJ, Pont-Sunyer C, Cucurella G, Fernández M, et al. Cerebral salt wasting syndrome: review. Eur J Intern Med 2008;19(4):249-54.

4) Yee AH, Burns JD, Wijdicks EF. Cerebral salt wasting: pathophysiology, diagnosis, and treatment. Neurosurg Clin N Am 2010;21(2): $339-52$.

5) Kim J, Moon IS, Lee JD, Shim DB, Lee WS. Useful surgical techniques for facial nerve preservation in tumorous intra-temporal lesions. Auris Nasus Larynx 2010;37(1):33-41.

6) Briggs RJ, Luxford WM, Atkins JS Jr, Hitselberger WE. Translabyrinthine removal of large acoustic neuromas. Neurosurgery 1994;34 (5):785-90; discussion 790-1.

7) Darrouzet V, Guerin J, Aouad N, Dutkiewicz J, Blayney AW, Bebear JP. The widened retrolabyrinthe approach: a new concept in acoustic neuroma surgery. J Neurosurg 1997;86(5):812-21.

8) Kaylie DM, Gilbert E, Horgan MA, Delashaw JB, McMenomey SO. Acoustic neuroma surgery outcomes. Otol Neurotol 2001;22(5):686-9.

9) Mass SC, Wiet RJ, Dinces E. Complications of the translabyrinthine approach for the removal of acoustic neuromas. Arch Otolaryngol Head Neck Surg 1999;125(7):801-4.

10) Roche PH, Ribeiro T, Fournier HD, Thomassin JM. Vestibular schwannomas: complications of microsurgery. Prog Neurol Surg 2008; 21:214-21.

11) Jiménez R, Casado-Flores J, Nieto M, García-Teresa MA. Cerebral salt wasting syndrome in children with acute central nervous system injury. Pediatr Neurol 2006;35(4):261-3.

12) Betjes MG. Hyponatremia in acute brain disease: the cerebral salt wasting syndrome. Eur J Intern Med 2002;13(1):9-14.

13) Uygun MA, Ozkal E, Acar O, Erongun U. Cerebral salt wasting syndrome. Neurosurg Rev 1996;19(3):193-6.

14) Harrigan MR. Cerebral salt wasting syndrome: a review. Neurosurgery 1996;38(1):152-60.

15) Day JD, Chen DA, Arriaga M. Translabyrinthine approach for acoustic neuroma. Neurosurgery 2004;54(2):391-5; discussion 395-6.

16) Enée V, Guérin J, Bébéar JP, Darrouzet V. [Acoustic neuroma surgery. Results and complications in 348 cases]. Rev Laryngol Otol Rhinol (Bord) 2003;124(1):45-52. 